\title{
Review of Caryocolum (Lepidoptera: Gelechiidae) from the Russian Altai with description of two new species
}

\author{
Jan ŠUMPICH ${ }^{1)}$, Peter HUEMER ${ }^{2)} \&$ Oleksiy BIDZILYA $^{3)}$ \\ ${ }^{1)}$ National Museum, Department of Entomology, Cirkusová 1470, CZ-193 00 Praha 9 - Horní Počernice, Czech Republic; \\ e-mail: jansumpich@seznam.cz \\ 2) Tiroler Landesmuseen Betriebsges.m.b.H., Natural History Collections, Krajnc-Str. 1, A-6060 Hall in Tirol, Austria; \\ e-mail: p.huemer@tiroler-landesmuseen.at \\ ${ }^{3)}$ Institute for Evolutionary Ecology of the National Academy of Sciences of Ukraine, 37 Academician Lebedev str., 03143, Kiev, Ukraine; \\ e-mail:olexbid@gmail.com
}

Accepted:

$22^{\text {nd }}$ January 2020

Published online: $29^{\text {th }}$ February 2020

\begin{abstract}
In total, thirteen species of the genus Caryocolum Gregor \& Povolný, 1954 (Lepidoptera: Gelechiidae) have been recorded from the Altai mountains in Russia so far. All available faunistic data are summarized and presented in detail. DNA barcodes of the mtCOI (cytochrome c oxidase I) gene of the majority of recorded species were studied. Molecular data and morphology support the following two species, which are described here as new to science: Caryocolum procurvella sp. nov. and C. atrum sp. nov. Caryocolum tetrameris (Meyrick, 1926) is recorded as a new species for Russia. Caryocolum blandella (Douglas, 1852 ) and C. viscariella (Stainton, 1855) are removed from the fauna of the Altai Republic due to misidentifications.
\end{abstract}

Key words. Lepidoptera, Gelechiidae, cytochrome c oxidase I, DNA barcoding, genetic distances, taxonomy, Altai Republic, Khakassia, southern Ural, Mongolia, Russia, Palaearctic Region

Zoobank: http://zoobank.org/urn:lsid:zoobank.org:pub:F95C6194-BC8E-4C53-929E-930FD4479ABC

(C) 2020 The Authors. This work is licensed under the Creative Commons Attribution-NonCommercial-NoDerivs 3.0 Licence.

\section{Introduction}

The Holarctic genus Caryocolum Gregor \& Povolný, 1954 , is a particularly diverse genus of Gelechiidae. European taxa were repeatedly revised (KLIMESCH 1953-1954, HuEMER \& KARSHOLT 2010), and recently genetic data were obtained for the majority of species from this contintent (Huemer et al. 2014, 2020). Besides this revisionary work only four new species have been described during the last decade, namely Caryocolum srnkai Huemer \& Karsholt, 2011, C. dauphini Grange \& Nel, 2012, C. crypticum Huemer, Karsholt \& Mutanen, 2014, and C. tedosella Nel \& Requena, 2017 (Huemer \& Karsholt 2011, Huemer et al. 2014, Grange \& Nel 2012, Nel \& Requena 2017). The Asian fauna of Caryocolum was revised by HUEMER (1988), with many additional species descriptions afterwards (Huemer 1989, 1992; Li \& Zheng 1995; Falkovitsh \& Bidzilya 2006; Bidzilya \& Nupponen 2018). According to PonOMARENKo (2008) the Russian fauna comprises twenty
Caryocolum species whereas only C. repentis Huemer \& Luquet, 1992, C. unicolorellum Bidzilya, 2018, and $C$. petrophilum (Preissecker, 1914) have been added to the Asian part of Russia during the last decade (JunNILAINEN et al. 2010, Huemer \& Karsholt 2010, Bidzilya \& NuPPONEN 2018). However, our extensive material from the Altai Mountains clearly indicates a much richer fauna, which is not really surprising as the Altai Mts. belong to the most interesting massifs of southern Siberia with high Lepidoptera species diversity. Several lepidopterologists visited the area in the past, resulting in many new records, including discoveries of undescribed species from various families (e.g. BiDZILYA et al. 2006, 2019; UstJuZHANin \& Kovtunovich 2017, Gaedike \& Šumpich 2017, Buchner et al. 2019, Sumpich et al. 2019, etc.). The aim of this work is to provide an overview of all Caryocolum species from the Russian Altai, including genetic data if available, and to describe two species new for science. 


\section{Material and methods}

The adults were collected by light trapping or by hand netting. Male and female genitalia were dissected and prepared using standard methods (HUEMER \& KARSHOLT 2010). Pinned specimens were photographed with a Canon 750D camera with a Canon MP-E-65 mm lens. Slide-mounted genitalia were photographed with a Canon EOS 1100D camera mounted on an Olympus BX41 stereomicroscope.

Forty-seven specimens of Caryocolum recorded in the Altai Mts. were successfully barcoded at the Canadian Centre for DNA Barcoding (CCDB, Biodiversity Institute of Ontario, University of Guelph). In all cases we obtained a full 658 base-pair long segment of the 5 ' terminus of cytochrome c oxidase gene; the sequences together with details of the sequenced specimens were uploaded to the Barcode of Life Data Systems (BOLD; Ratnasingham \& HEBert 2007). All data are avalaible in the public dataset „DS-CARALT Caryocolum of Altai" (dx.doi.org/10.5883/DS-CARALT); newly generated sequences were also submitted to GenBank under accession numbers MN942335-MN942375. The sequences were downloaded from BOLD using implemented Muscle multiple alignment algorithm (EDGAR 2004) and subsequently edited and analyzed in MEGAX software (KUMAR et al. 2018). Tamura 3-parameter model (TAMURA 1992) with uniform rates was suggested as the best model for the data and it was used during the calculations of genetic distances and phylogenetic trees. Maximum likelihood method was used including 1000 bootstrap replications for the trees. We present the Barcode Index Numbers (BIN) (RATNASINGHAM \& HEBERT 2013) for each barcoded species.

In the descriptions, the terminology of the genitalia and with some adaptations the sequence of species follows Huemer (1988). In the terms of this paper, the Altai Republic and the Russian Altai Mountains are considered one area.

The present contribution is based on material deposited in the following collections:

FMNH Finnish Museum of Natural History, Helsinki, Finland;

JUNN Jari JunnilainenVantaa Research Collection, Espoo, Finland;

LMK Landesmuseum Kärnten, Klagenfurt, Austria;

NMPC National Museum, Prague, Czech Republic;

NUPP Kari \& Timo Nupponen Research Collection, Espoo, Finland;

SMNK Staatliches Museum für Naturkunde, Karlsruhe, Germany;

TLMF Tiroler Landesmuseum Ferdinandeum, Innsbruck, Austria;

ZIN Zoological Institute, Russian Academy of Sciences, Sankt-Petersburg, Russia;

ZMKU Zoological Museum Kiev Taras Shevchenko National University, Kiev, Ukraine;

ZMUC Zoological Museum, Natural History Museum of Denmark, Copenhagen, Denmark

\section{Results}

\section{Caryocolum alsinella (Zeller, 1868)}

Records. Bidzilya (2002, as C. viscariella Stainton, 1855, misidentification); HUEMER et al. (2017).

Material examined. RUSSIA: Altai Republic: Katun valley, $10 \mathrm{~km} \mathrm{~W}$ Katanda, 1200 m a.s.1., 15.-19.vii.1983, $2 \precsim 2 \bigcirc \bigcirc$ (gen. slide 94/482, P. Huemer), K. Mikkola, H. Hippa et J. Jalava leg. (FMNH); Chemal district, $2 \mathrm{~km} \mathrm{SW}$ of Chemal, $450 \mathrm{~m}$ a.s.1., $51^{\circ} 22^{\prime} 59.90^{\prime \prime} \mathrm{N}, 85^{\circ} 58^{\prime} 59.96^{\prime \prime} \mathrm{E}$, 8.-9. viii.2016, 1 (Barcode TLMF Lep 21256), P. Huemer \& B. Wiesmair leg.

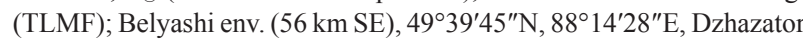

valley, mountain meadows near Tara river, $2300 \mathrm{~m}, 25 .-26 . v i i .2017$, $1 \hat{\jmath}$ (Barcode NMPC-LEP-0368), J. Šumpich leg. (NMPC); Belyashi (Dzhazator) env. (25 km NW), confluence of Argut and Karagem rivers, $49^{\circ} 51^{\prime} 56^{\prime \prime} \mathrm{N}, 87^{\circ} 10^{\prime} 22^{\prime \prime} \mathrm{E}$, rocky steppe, $1400 \mathrm{~m}, 27 .-28 . v i i .2017,1$ (Barcode NMPC-LEP-0357), J. Šumpich leg. (NMPC); Kosh-Agatch distr., $30 \mathrm{~km} \mathrm{~W}$ of Dzhazator, Koksu river, $1600 \mathrm{~m}$ a.s.1., 20.viii.2000, 12 $\hat{\jmath}$, O. Bidzilya leg. (ZMKU); Kosh-Agatch distr., $5 \mathrm{~km}$ E of Dzhazator, 1500 m a.s.1., 22.viii.2000, $2 \AA \hat{\jmath}$, O. Bidzilya leg. (ZMKU).

Molecular data. BIN BOLD: AAV0572 ( $\mathrm{n}=21,5$ public, 3 from the Altai). The average intraspecific divergence of the barcode region is $0.64 \%$ (maximum $1.77 \%$ ). The nearest neighbour is C. oculatella with $3.53 \%$ p-distance.

Distribution. Europe, Morocco (HUEMER 1988), Turkey, Central Asia (Huemer \& Karsholt 2010), Russia: the Altai Republic, South of Krasnoyarskiy krai, South of Khabarovkiy krai (PonOMARENKo 2008, HuEMER et al. 2017, AKulov et al. 2018).

\section{Caryocolum arenariella (Benander, 1937) (Fig. 1)}

Records. HuEmer et al. (2017, as C. schleichi Christoph, 1872). Material examined. RUSSIA: Altai RePUblic: Ulagan district, $11 \mathrm{~km}$

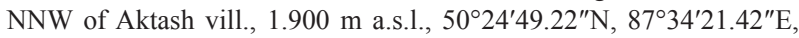
28.-30.vii.2016, $8 \curvearrowright \hat{\jmath}$, P. Huemer \& B. Wiesmair leg. (TLMF); Ulagan district, $10 \mathrm{~km}$ NE Aktash village, Kuraj Mts range, between Korumdyajry and Yarlyamry rivers, $2150 \mathrm{~m}$ a.s.1., $50^{\circ} 19^{\prime} \mathrm{N}, 8^{\circ} 43^{\prime} \mathrm{E}, 6 .-8 . v i i i .2016,11$ o 1 9, P. Huemer \& B. Wiesmair leg. (TLMF); Kosh-Agach district, 17 km NNE of Kokorya, Chikhacheva Mountains Range, Talduair Moun-

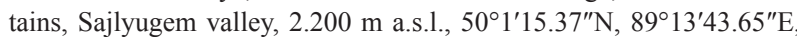
30.vii.-2.viii.2016, $13 \hat{\partial} \partial$ (gen. slide GEL 1259 , GEL $1260 \hat{\jmath}$, P. Huemer) (Barcode TLMF Lep 20329, Barcode TLMF Lep 20330, Barcode TLMF Lep 20331), P. Huemer \& B. Wiesmair leg. (TLMF); Kosh-Agach district, $10 \mathrm{~km}$ NE of Kosh-Agach, Kurai Mountains Range, Tabozhok valley, $2.100 \mathrm{~m}$ a.s.1., 50॰4'32.36"N, 8843'41.83"E, 2.-4.viii.2016, 1 (Barcode KLM Lep 06375), C. Wieser leg. (LMK); Belyashi env. (56 km $\mathrm{SE}), 49^{\circ} 39^{\prime} 45^{\prime \prime} \mathrm{N}, 88^{\circ} 14^{\prime} 28^{\prime \prime} \mathrm{E}$, Dzhazator valley, mountain meadows near Tara river, $2300 \mathrm{~m}, 25 .-26 . v i i .2017,17 \delta \hat{\jmath}$ (Barcode NMPC-LEP-0370), J. Šumpich leg. (NMPC); Belyashi (Dzhazator) env. (25 km NW), confluence of Argut and Karagem rivers, 49 $51^{\prime} 56^{\prime \prime} \mathrm{N}, 87^{\circ} 10^{\prime} 22^{\prime \prime} \mathrm{E}$, rocky steppe, 1400 m, 27.-28.vii.2017, $7 \lesssim 1$ \%, J. Šumpich leg. (NMPC).

Molecular data. BIN BOLD: AAE9479 $(\mathrm{n}=10,5$ public, 5 from the Altai). The average intraspecific divergence of the barcode region is $0.6 \%$ (maximum $1.31 \%$ ). The nearest neighbour is $C$. schleichi (Christoph, 1872) with $2.25 \%$ p-distance.

Distribution. Europe: southern Scandinavia, the Baltic countries, Macedonia, Mongolia, Russia: the Altai Republic, Zabaikalskiy krai, Middle Amur (HuEMER \& Karsholt 2010, Ponomarenko 2016, Huemer et al. 2017).

Remark. Until recently, Caryocolum arenariella was treated as a subspecies of C. schleichi (Christoph, 1872). Based on a recent study it was re-elevated to the species level (AARVIK et al. 2017).

\section{Caryocolum cassella (Walker, 1864)} (Fig. 2)

Records. BIDZILYA (2009).

Material examined. RUSSIA: Altai Republic: Teletskoe lake, Artybash Biol. St., 18.-22.viii.1982, 1 dै, Mikkola leg. (FMNH); Katun valley, 15 $\mathrm{km} \mathrm{S}$ of Katanda, $1200 \mathrm{~m}$ a.s.1., taiga, 2.-25.vii.1983, 13 के 2 우, K. Mikkola, H. Hippa \& J. Jalava leg. (FMNH); Ust'-Sema district, Kamlak env., 6.vii.2001, 1 , at light, O. Bidzilya leg. (ZMKU); Aktash vill., $50^{\circ} 19^{\prime} 12^{\prime \prime} \mathrm{N}, 87^{\circ} 36^{\prime} 00^{\prime \prime} \mathrm{E}, 1400 \mathrm{~m}$ a.s.l., grassy steppe, rocks, 11.vii.2014,

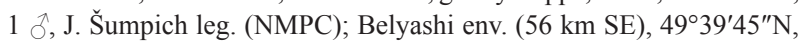




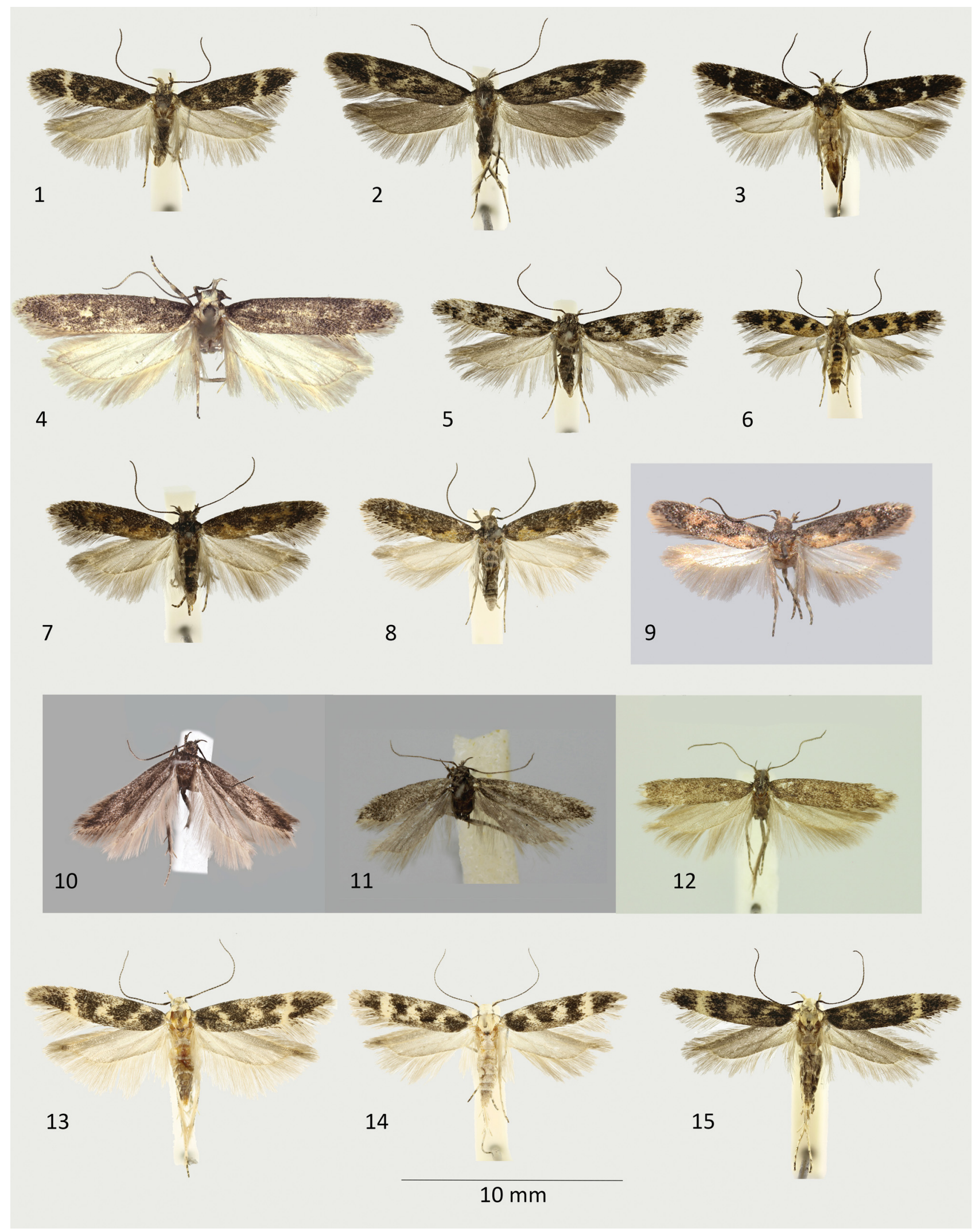

Figs 1-15. Adults of some Caryocolum species. 1 - C. arenariella (Benander, 1937), Dzhazator, male; 2 - C. cassella (Walker, 1864), Dzhazator, male; $3-$ C. leucomelanella (Zeller, 1839), Chulyshman, male; 4 - C. mongolense Povolný, 1969, Beltir, male; 5 - C. petrophilum (Preissecker, 1914), Karagem, male; 6 - C. petryi (Hofmann, 1899), Karagem, female; 7-9 - C. procurvella sp. nov., males: 7 - Karagem, holotype; 8 - Karagem, paratype; 9-S Ural, Arkaim, paratype; 10-12 - C. atrum sp. nov.: 10 - holotype, Ukok Plateau; 11-12 - paratypes: 11 - Beltir; 12 - Mongolia, Chövsgöl aimak; 13-15-C. tetrameris (Meyrick, 1926): 13-14 - Dzhazator, males, 15 - Aktash, female. 


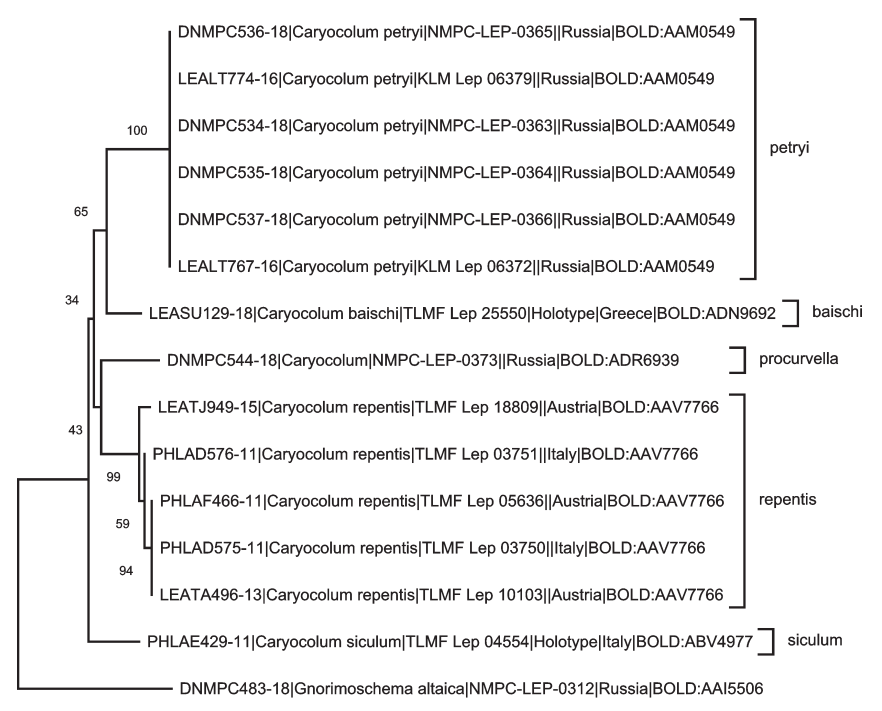

$\mapsto$

0.010

Fig. 16. Maximum likelihood tree based on DNA barcodes of the specimens from the Caryocolum petryi group with Gnorimoschema altaica Bidzilya, Huemer, Nupponen \& Šumpich, 2019 as an outgroup species (for sources see in Material and methods).

$88^{\circ} 14^{\prime 2} 8^{\prime \prime}$ E, Dzhazator valley, mountain meadows near Tara river, 2300 m, 25.-26.vii.2017, $6 \lesssim 3$ \% (Barcode NMPC-LEP-0371, Barcode NMPC-LEP-0379), J. Šumpich leg. (NMPC); Belyashi (Dzhazator) env. $(25 \mathrm{~km} \mathrm{NW})$, confluence of Argut and Karagem rivers, 49 $51^{\prime} 56^{\prime \prime} \mathrm{N}$, $87^{\circ} 10^{\prime} 22^{\prime \prime} \mathrm{E}$, rocky steppe, $1400 \mathrm{~m}, 27 .-28 . v i i .2017,4 \delta 1 \uparrow$ (Barcode NMPC-LEP-0372, NMPC-LEP-0380), J. Šumpich leg. (NMPC).

Molecular data. BIN BOLD: ACX4318 ( $\mathrm{n}=49,34$ public, 4 from the Altai), AAM7959 $(n=26,26$ public, 0 from the Altai). The average intraspecific divergence of the barcode region of the first cluster is $0.43 \%$ (maximum $1.16 \%$ ), and $0.41 \%$ (maximum $0.81 \%$ ) of the second one. Whereas the second cluster (BIN AAM7959) comprises exclusively records from Canada, in the first cluster (BIN ACX4318) records from Canada and the whole Palaearctic are merged. The average distance between these clusters is $1.37 \%$.

Distribution. Holarctic. In Europe as well as in Russia predominantly in the mountains (BIDZILYA 2002, 2009; HUEMER \& KarShOLT 2010).

Remark. Large material from the Holarctic Region was examined, and no distinct differences in habitus or genitalia were found (HUEMER 1988, HuEMER \& KARSHOLt 2010, NAZARI \& LANDRY 2012). We therefore consider both genetic clusters conspecific.

\section{Caryocolum junctella (Douglas, 1851)}

Records. BIDZILYA (2002).

Material examined. RUSSIA: Altai Republic: Teletskoe lake, Artybash Biol. St., 18.-22.viii.1982, 1 (GU 94/478, P. Huemer), Mikkola leg. (FMNH); Gorno-Altaisk, 15.vii.1998, 1 , A. Lvovsky leg. (ZIN); Katun valley, $600 \mathrm{~m}$ a.s.1., near Ust-Sema village, $51^{\circ} 40^{\prime} \mathrm{N} 85^{\circ} 45^{\prime} \mathrm{E}$, 1.vii.2001, $1 \delta$ (gen. slide 248/19, O. Bidzilya), K. Nupponen leg. (NUPP).

Molecular data. BIN BOLD: AAQ1185 $(\mathrm{n}=6,5$ public, 0 from the Altai), ACY8911 $(n=5,5$ public, 0 from the Altai). The average intraspecific divergence of the barcode region of the first cluster is $0.06 \%$ (maximum $0.17 \%$ ), and $0.32 \%$ (maximum $0.48 \%$ ) of the second one. The average divergence between these clusters is $1.77 \%$.

Distribution. From Europe to Japan, Korea and China (Huemer \& Karsholt 2010).

\section{Caryocolum leucomelanella (Zeller, 1839) (Fig. 3)}

Records. BIDZILYA (2002), HUEMER et al. (2017).

Material examined. RUSSIA: Altai Republic: Katun valley, $10 \mathrm{~km} \mathrm{~W}$ Katanda, 1200 m a.s.1., 15.-19.vii.1983, 4 §ิ đ, K. Mikkola, H. Hippa \& J. Jalava leg. (FMNH); Katun valley, $15 \mathrm{~km} \mathrm{~S}$ Katanda, $1200 \mathrm{~m}$ a.s.l., taiga, 23.-25.vii.1983, 3 §ิ đ, K. Mikkola, H. Hippa \& J. Jalava leg. (FMNH); Kosh-Agatch distr., $30 \mathrm{~km}$ W of Dzhazator, Koksu river, $1600 \mathrm{~m}$ a.s.1., 19.-20.viii.2000, $11 \AA \partial$, O. Bidzilya leg. (ZMKU); Kosh-Agatch distr., $5 \mathrm{~km}$ E of Dzhazator, $1500 \mathrm{~m}$ a.s.1., 22.viii.2000, 27.vii.2001, $3 \AA \AA$, O. Bidzilya leg. (ZMKU); Kuraisky hrebet, 50 $16-20^{\prime} \mathrm{N} 87^{\circ} 50-55^{\prime} \mathrm{E}, 2300$ $\mathrm{m}$ a.s.1., 11. and 13.vii.2001, $1 \delta$ (gen. slide 177/18; 225/19, O. Bidzilya), K. Nupponen leg. (NUPP); Kuraisky hrebet, $51^{\circ} 00-10^{\prime} \mathrm{N} 85^{\circ} 33-45^{\prime} \mathrm{E}$,

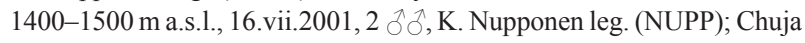
valley, $5 \mathrm{~km}$ SE of Aktash village, $50^{\circ} 14-16^{\prime} \mathrm{N} 87^{\circ} 40^{\prime} \mathrm{E}, 1500 \mathrm{~m}$ a.s.l., 14.vii.2001, $1 \hat{\jmath}$, K. Nupponen leg. (NUPP); Ulagan district, $11 \mathrm{~km} \mathrm{NNW}$ of Aktash vill., $1.900 \mathrm{~m}$ a.s.1., 50²4'49.22"N , 87³4'21.42" E, 28.-30. vii.2016, $13 \AA \widehat{\partial}$ (Barcode TLMF Lep 20239, TLMF Lep 20240, TLMF Lep 20241, TLMF Lep 20275), P. Huemer \& B. Wiesmair leg. (TLMF); same data, (Barcode KLM Lep 06380), C. Wieser leg. (LMK); Kosh-Agach district, 17 km NNE of Kokorya, Chikhacheva Mountains Range, Talduair Mountains, Sajlyugem valley, $2.200 \mathrm{~m}$ a.s.1., 50 $1^{\prime} 15.37^{\prime \prime} \mathrm{N}$, $89^{\circ} 13^{\prime} 43.65^{\prime \prime}$ E, 30.vii.-2.viii.2016, 1 ô, P. Huemer \& B. Wiesmair leg. (TLMF); Ulagan district, $10 \mathrm{~km}$ NE Aktash village, Kuraj Mts range, between Korumdyajry and Yarlyamry rivers, $2150 \mathrm{~m}$ a.s.1., $50^{\circ} 19^{\prime} \mathrm{N}$, $87^{\circ} 43^{\prime} \mathrm{E}, 6 .-8 . v i i i .2016,10 \delta^{\jmath}$, P. Huemer \& B. Wiesmair leg. (TLMF); Chemal district, $2 \mathrm{~km} \mathrm{SW}$ of Chemal, $450 \mathrm{~m}$ a.s.1., $51^{\circ} 22^{\prime} 59.90^{\prime \prime} \mathrm{N}$, 85 58'59.96"E, 8.-9.viii.2016, 1 (Barcode TLMF Lep 21234), P. Huemer \& B. Wiesmair leg. (TLMF); Belyashi env. (56 km SE), 49³9'45"N, $88^{\circ} 14^{\prime} 28^{\prime \prime} \mathrm{E}$, Dzhazator valley, mountain meadows near Tara river, 2300 m, 25.-26.vii.2017, 1 † (Barcode NMPC-LEP-0377), J. Šumpich leg. (NMPC); Belyashi (Dzhazator) env. (25 km NW), confluence of Argut and Karagem rivers, $49^{\circ} 51^{\prime} 56^{\prime \prime} \mathrm{N}, 87^{\circ} 10^{\prime} 22^{\prime \prime} \mathrm{E}$, rocky steppe, $1400 \mathrm{~m}, 27 .-28$. vii.2017, 1 (Barcode NMPC-LEP-0367), J. Šumpich leg. (NMPC);

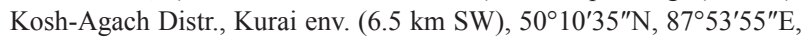
grassy steppe, $1550 \mathrm{~m}, 30 . v i i .2017,1 \lesssim$ (Barcode NMPC-LEP-0376), J. Sumpich leg. (NMPC); $45 \mathrm{~km} \mathrm{~N}$ of Ulagan vill., Chulyshman valley, $51^{\circ} 01^{\prime} 03^{\prime \prime} \mathrm{N}, 88^{\circ} 00^{\prime} 39^{\prime \prime} \mathrm{E}$, grassy steppe, rocks, $600 \mathrm{~m}, 27 .-28 . v i .2015,2$ $\delta \widehat{\partial}$ (Barcode NMPC-LEP-0378), J. Šumpich leg. (NMPC).

Molecular data. BIN BOLD: AAM3503 ( $\mathrm{n}=38,24$ public, 10 from the Altai), ACI3418 ( $n=4,4$ public, 0 from the Altai). The average intraspecific divergence of the barcode region of the first cluster is $0.85 \%$ (maximum $2.09 \%$ ), and $0.4 \%$ (maximum $0.64 \%$ ) of the second one. The average divergence between both clusters is $2.73 \%$. The moths from the second cluster (BIN ACI3418) possibly belong to a new species but require further revisionary work.

Distribution. From Europe (central and southern parts) across Turkey to Zabaikalskiy krai of Russia (PonOMARENKo 2008, HuEMER \& Karsholt 2010).

\section{Caryocolum mongolense Povolný, 1969 (Figs 4, 17)}

Records. BIDZILYA (2002).

Material examined. RUSSIA: AltaI Republic: Kosh-Agatch distr., 15 $\mathrm{km}$ from Beltir up along Tchagan river, $2200 \mathrm{~m}$ a.s.1., steppe, 14.viii.2000, $2 \delta^{\widehat{\jmath}}$ (gen. slide 192/18, O. Bidzilya), O. Bidzilya leg. (ZMKU).

Molecular data. No data are avalaible. 
Distribution. Mongolia (HuEmer 1988), Russia: the Altai Republic. The records from the Altai are the only ones from Russia so far (see also BiDzILYA 2002).

\section{Caryocolum oculatella (Thomann, 1930)}

Records. BiDZILYA (2002), HUEMER et al. (2017).

Material examined. RUSSIA: Altai Republic: Ongudai distr., 15 km lower of Iodro vill., along Tchuja river, 6.viii.2000, 1 $\curvearrowright$, O. Bidzilya leg.; Ongudai distr., Maliy Jaloman, $700 \mathrm{~m}$ a.s.1., 2.viii.2001, $9 \curvearrowright 1$, at light, O. Bidzilya leg. (all ZMKU); 1 ๆ, Kuraisky khrebet, $50^{\circ} 16-20^{\prime} \mathrm{N}$ 8750-55'E, $2300 \mathrm{~m}$ a.s.1., 11. and 13.vii.2001, 1 (gen. slide 224/19, O. Bidzilya), K. Nupponen leg. (NUPP); Kosh-Agach district, 10 km NE of Kosh-Agach, Kurai Mountains Range, Tabozhok valley, 2.100 m a.s.1., $50^{\circ} 4^{\prime} 32.36^{\prime \prime} \mathrm{N}, 88^{\circ} 43^{\prime} 41.83^{\prime \prime} \mathrm{E}, 2 .-4 . v i i i .2016,9{ }^{\prime} 1$, (Barcode TLMF Lep 20381, TLMF Lep 20382, TLMF Lep 20383), P. Huemer \& B. Wiesmair leg. (TLMF); Belyashi (Dzhazator) env. (25 km NW), confluence of Argut and Karagem rivers, $49^{\circ} 51^{\prime} 56^{\prime \prime} \mathrm{N}, 87^{\circ} 10^{\prime} 22^{\prime \prime} \mathrm{E}$, rocky steppe, 1400 m, 27.-28.vii.2017, $48 \lesssim 9$ 우, J. Šumpich leg. (NMPC); KoshAgach Distr., Kurai env. (15 km SW), Dzhangyskol lake, 50¹0'49"N; $87^{\circ} 44^{\prime} 19^{\prime \prime} \mathrm{E}$, coniferous forest/steppe, $1830 \mathrm{~m}, 24 .-25 . v i .2015,1$ §ै, J. Šmpich leg. (NMPC); Kosh-Agach Distr., Chagan-Uzun env., Krasnaya Gorka hill, 5005'00"N; 88 25'15"E, rocky steppe, 1870 m, 29.vi.2015, 1 ô, J. Šumpich leg. (NMPC); Kosh-Agach Distr., Kurai env. (6.5 km $\mathrm{SW}), 50^{\circ} 10^{\prime} 35^{\prime \prime} \mathrm{N}, 8^{\circ} 53^{\prime} 55^{\prime \prime} \mathrm{E}$, grassy steppe, $1550 \mathrm{~m}$, 9.-10.vii.2014, 1 †, 30.vii.2017, $2 \hat{\jmath} \delta$, J. Šumpich leg. (NMPC); Aktash vill., 17.-22. vii.2009, $10 \hat{\delta}$, (gen. slide GEL $1225 \hat{\jmath}$, GEL $1243 \hat{\partial}$, P. Huemer) (Barcode TLMF Lep 19842, TLMF Lep 19843), B. Schacht leg. (TLMF); Aktash vill., $50^{\circ} 19^{\prime} 12^{\prime \prime} \mathrm{N} ; 87^{\circ} 36^{\prime} 00^{\prime \prime} \mathrm{E}$, grassy steppe, rocks, $1400 \mathrm{~m}$, 11.vii.2014, $4 \hat{\jmath}$, J. Šumpich leg. (NMPC); $45 \mathrm{~km}$ N of Ulagan vill., Chulyshman valley, $51^{\circ} 01^{\prime} 03^{\prime \prime} \mathrm{N} ; 88^{\circ} 00^{\prime} 39^{\prime \prime} \mathrm{E}$, grassy steppe, rocks, 600 m, 27.-28.vi.2015, 4 우, J. Šumpich leg. (NMPC).

Molecular data. BIN BOLD: ABV4976 $(n=4,1$ public, 3 from the Altai). The average intraspecific divergence of the barcode region is $0.1 \%$ (maximum $0.15 \%$ ). The nearest neighbour is C. alsinella (Zeller, 1868) with $3.53 \%$ p-distance.

Distribution. The Alps (Switzerland, Austria), Mongolia (Povolný 1973, as Caryocolum pr. amaurellum; HuEMER 1988; Huemer \& KARShOlT 2010), Russia: the Altai Republic, South of Krasnoyarskiy krai, Zabaikalskiy krai (Bidzilya et al. 1998, Bidzilya 2002).

Remark. Caryocolum oculatella was described from the vicinity of Martina in Graubünden in Switzerland where it rarely occurs (LEPIFORUM 2019) whereas in the Altai mountains it belongs to the abundant species.

\section{Caryocolum petrophila (Preissecker, 1914) (Fig. 5)}

Records. Huemer \& Karsholt (2010), Huemer et al. (2017).

Material examined. RUSSIA: Altai Republic: Katun valley, $10 \mathrm{~km}$ W of Katanda, 1200 m a.s.1., 15.-27.vii.1983, $4 \curvearrowright 1$ (GU 94/471, P. Huemer), K. Mikkola, H. Hippa \& J. Jalava leg. (FMNH); Chemal district, $2 \mathrm{~km} \mathrm{SW}$ of Chemal, $450 \mathrm{~m}$ a.s.1., $51^{\circ} 22^{\prime} 59.90^{\prime \prime} \mathrm{N}, 85^{\circ} 58^{\prime} 59.96^{\prime \prime} \mathrm{E}$, 8.-9. viii..2016, 3 के (Barcode KLM Lep 06376, KLM Lep 06377, KLM Lep 06378), C. Wieser leg. (KLM); Belyashi (Dzhazator) env. (25 km NW), confluence of Argut and Karagem rivers, 49 $51^{\prime} 56^{\prime \prime} \mathrm{N}, 87^{\circ} 10^{\prime} 22^{\prime \prime} \mathrm{E}$, rocky steppe, $1400 \mathrm{~m}, 27 .-28 . v i i .2017,1 \delta$ (Barcode NMPC-LEP-0375), J. Šmpich leg. (NMPC).

Molecular data. BIN BOLD: AAO3809 ( $\mathrm{n}=17,11$ public, 4 from the Altai). The average intraspecific divergence of the barcode region is $0.92 \%$ (maximum $2.41 \%$ ). The nearest neighbour is C. huebneri (Haworth, 1828) with
4.98\% p-distance.

Distribution. Very local arctic-alpine distribution pattern in Europe (from France to Ural) (HuEMER 1988, JunNILAINEN et al. 2010), Central Asia and the Altai Republic of Russia (Huemer \& Karsholt 2010).

\section{Caryocolum petryi (Hofmann, 1899)}

(Fig. 6)

Records. Huemer et al. (2017).

Material examined. RUSSIA: Altai Republic: Kosh-Agach district, 10 $\mathrm{km}$ NE of Kosh-Agach, Kurai Mountains Range, Tabozhok valley, 2.100 m a.s.1., $50^{\circ} 4^{\prime} 32.36^{\prime \prime} \mathrm{N}, 88^{\circ} 43^{\prime} 41.83^{\prime \prime} \mathrm{E}, 2$. $-4 . v i i i .2016,2$ ôे (Barcode KLM Lep 06372, KLM Lep 06379), C. Wieser leg. (KLM); Belyashi (Dzhazator) env. ( $25 \mathrm{~km} \mathrm{NW}$ ), confluence of Argut and Karagem rivers, $49^{\circ} 51^{\prime} 56^{\prime \prime} \mathrm{N}, 87^{\circ} 10^{\prime} 22^{\prime \prime} \mathrm{E}$, rocky steppe, $1400 \mathrm{~m}, 27 .-28$.vii.2017, 6 ○े 5 of (Barcode NMPC-LEP-0363, NMPC-LEP-0364, NMPC-LEP-0365, NMPC-LEP-0366), J. Šumpich leg. (NMPC).

Molecular data. BIN BOLD: AAM0549 ( $\mathrm{n}=14,8$ public, 6 from Altai). The average intraspecific divergence of the barcode region is $0.15 \%$ (maximum $0.64 \%$ ). The nearest neighbour is C. baischi Huemer \& Karsholt, 2010 with $3.37 \%$ p-distance.

Distribution. Palaearctic. In Russia it is known only from the Altai Republic and Zabaikalskiy krai (BIDZILYA 2005, HuEmer et al. 2017). Material published by PovolnÝ (1973) from Mongolia as C. pr. repentellum (=C. repentis) actually belongs to $C$. petryi.

Remark. Material from the Altai Mts. resembles rather the nominotypical population from Germany (Thuringia) than the darker and smaller specimens from Sweden (Öland) that were described as the subspecies benanderi (Hering, 1933). Similar dark, but larger specimens also occur in the Baltic countries and SE Poland, and furthermore in higher regions of the Alps.

\section{Caryocolum procurvella sp. nov. (Figs 7-9, 18)}

Records. Junnilainen et al. (2010, as C. repentis Huemer \& Luquet, 1992); AkuLov et al. (2019, as C. repentis).

Type material. Holotype: (NMPC): RUSSIA: Altai Republic: Belyashi (Dzhazator) env. (25 km NW), confluence of Argut and Karagem rivers, $49^{\circ} 51^{\prime} 56^{\prime \prime} \mathrm{N}, 87^{\circ} 10^{\prime} 22^{\prime \prime} \mathrm{E}$, rocky steppe, $1400 \mathrm{~m}$ a.s.l. (Barcode NMPC-LEP-0373), J. Šmpich leg. ParatyPe: 1 (NMPC): the same collecting data as holotype, gen. prep. Šumpich 19979. CheliabinsK District: Arkaim reserve near Amurskii village, 9.vii.1997, $1 \hat{\text { (gen. }}$ prep. 00021901 J. Junnilainen), K. Nupponen \& J. Junnilainen leg. (JUNN).

Description. Adult (Figs 7-9). Wingspan 11.5-12.5 mm. Segment 2 of labial palpus creamy suffused with brown scales on inner and outer surface, lighter near base; segment 3 black. Antenna unicolorous, black. Head and tegulae dark brown with dark bronze, close-fitting scales; thorax dark brown. Forewing dark brown in basal, costal and apical parts, subtly suffused with whitish scales; dorsum distinctly rusty, this light patch does not reach base; rusty scales indistinctly also in $2 / 3$ from base; costal and tornal spots indistinct. Hindwing light grey, slightly darker near costa and apex.

Variation. In lighter specimens dorsum and costal and tornal spots can be more distinct. 

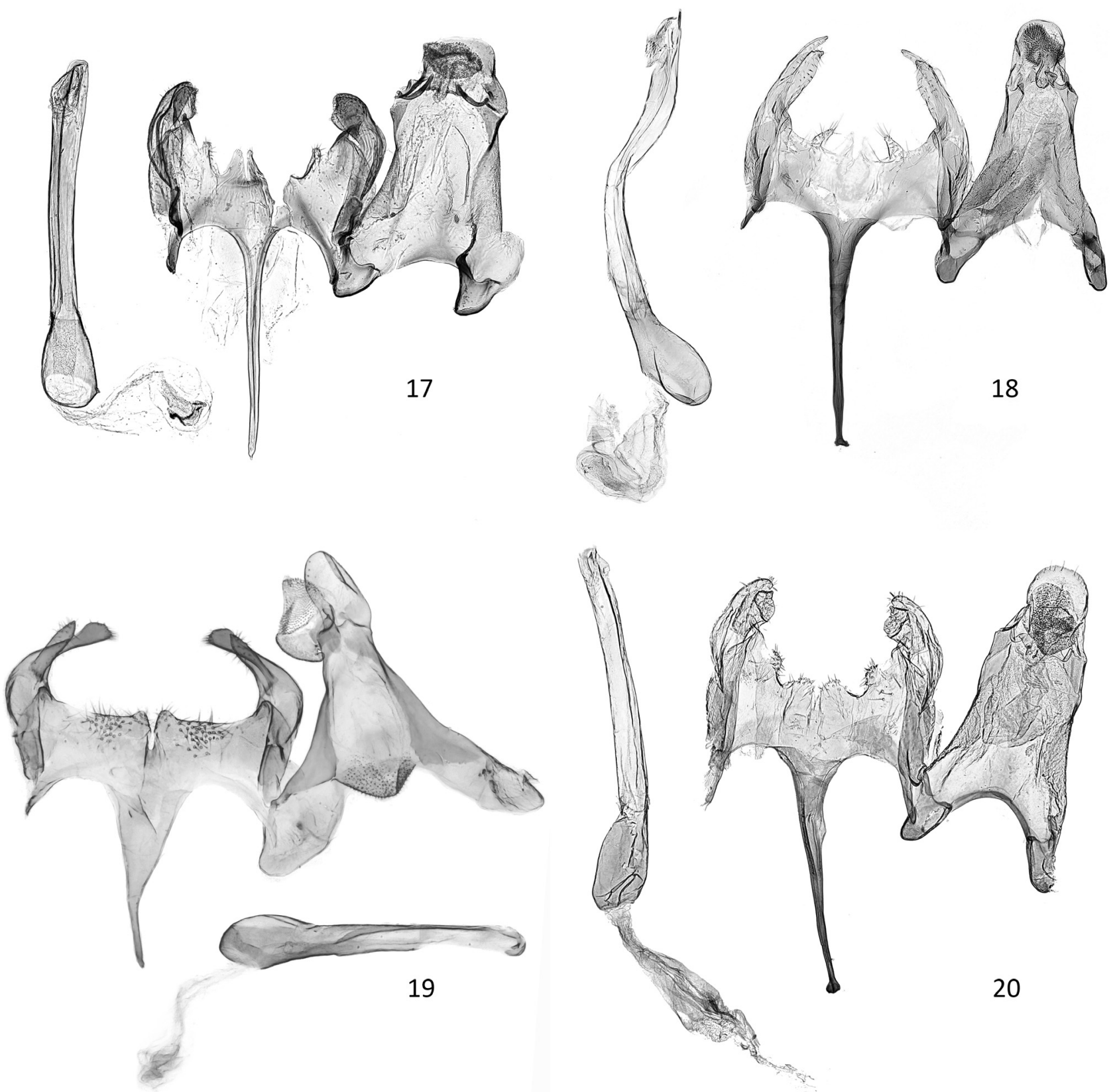

Figs 17-20. Male genitalia of some Caryocolum species recorded from Altai Mts. 17 - C. mongolense Povolný, 1969, gen. prep. Bidzilya 192/18; 18 - C. procurvella sp. nov.; gen. prep. Šumpich 19979; 19 - C. atrum sp. nov., gen. prep. Huemer 1277; 20 - C. tetrameris (Meyrick, 1926), gen. prep. Sumpich 19985. Phalli to the same scale as genitalia.

Male genitalia (Fig. 18). Uncus subrectangular, apically rounded; tegumen slender, comparatively greatly emarginate anteriorly; valva narrow, short, not reaching top of uncus, bluntly pointed; sacculus shorter and broader compared with valva, very slightly curved, apically pointed; posterior margin of vinculum with two medial triangular processes and two lateral digitate processes, approximately of same length as those in middle; saccus comparatively long, moderately extending towards base; phallus very long and slender, approximately twice longer compared to tegumen complex, S-curved, apex pointed, with some minute cornuti.

Female genitalia. Unknown.

Differential diagnosis. Caryocolum procurvella is externally similar to several species of the C. petryi group, particularly to C. repentis, C. baischi Huemer \& Karsholt, 2010, and C. siculum Bella, 2008. It differs from these species in the indistinct costal and tornal spots, the unicolorous dark thorax, and the generally less contrasting appearance of forewings. Moreover, the rusty dorsal patch is separated from base in C. procurvella but associated with it in C. repentis and C. siculum. In the male genitalia, C. repentis is the most similar species but it has shorter (1/3 length of lateral) medial projection of the vinculum, a comparatively shorter saccus and an apically nearly rounded (rather than pointed as in C. procurvella) valva (see e.g. Huemer \& Karsholt 2010). From other related species, C. procurvella differs in the shape of processes of the posterior margin of the vinculum and the significantly S-curved phallus. 


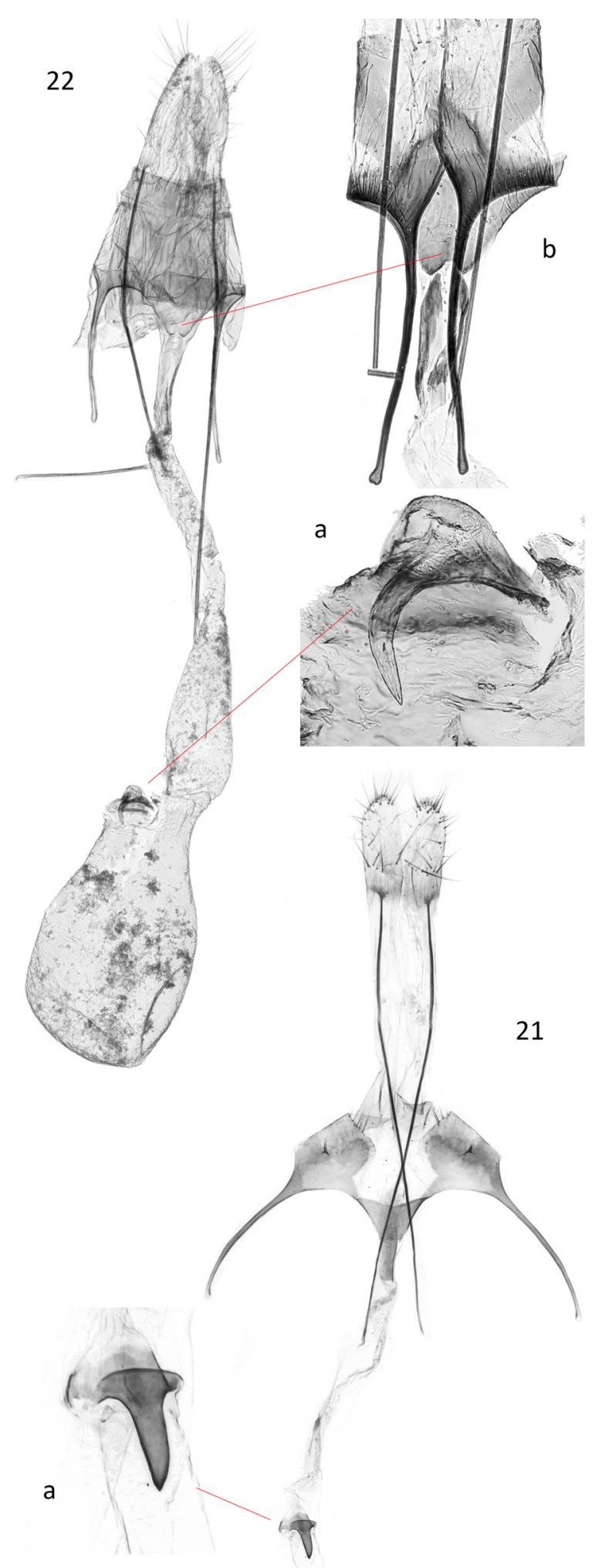

Figs 21-22. Female genitalia of some Caryocolum species recorded from Altai Mts. $21-$ C. atrum sp. nov., gen. prep. Huemer 1278; a - signum (enlarged); 22 - C. tetrameris (Meyrick, 1926), gen. prep. Šumpich 19984; a - detail of antrum (enlarged) (gen. prep. Bidzilya 286/17); $\mathrm{b}$ - signum (enlarged).
Table 1. Mean genetic distances in \% between Caryocolum procurvella sp. nov. and related taxa (lower left part) with standard deviations of distances (upper right part)

\begin{tabular}{|lc|c|c|c|c|c|}
\cline { 2 - 7 } \multicolumn{1}{c|}{} & $\mathbf{1}$ & $\mathbf{2}$ & $\mathbf{3}$ & $\mathbf{4}$ & $\mathbf{5}$ \\
\hline Caryocolum procurvella & $\mathbf{1}$ & - & 0.78 & 0.87 & 0.77 & 0.88 \\
\hline Caryocolum repentis & $\mathbf{2}$ & 3.75 & - & 0.73 & 0.78 & 0.82 \\
\hline Caryocolum siculum & $\mathbf{3}$ & 4.57 & 3.41 & - & 0.78 & 0.81 \\
\hline Caryocolum baischi & $\mathbf{4}$ & 3.75 & 3.93 & 3.91 & - & 0.68 \\
\hline Caryocolum petryi & $\mathbf{5}$ & 4.94 & 4.63 & 4.62 & 3.47 & - \\
\hline
\end{tabular}

Etymology. The species name is derived from the Latin word procurvus (curved), referring to the characteristic shape of the phallus; noun in apposition.

Biology. Unknown. Adults were collected in rocky steppe with sparse vegetation in $1400 \mathrm{~m}$ a.s.l. (Figs 25-26). The closely related species C. repentis lives on Gypsophila repens L. (Caryophyllaceae), and it is expected that $C$. procurvella develops on Gypsophila species, too.

Molecular data. BIN BOLD: ADR6939 ( $\mathrm{n}=1,1$ public, 1 from the Altai). The nearest neighbours are $C$. repentis and C. baischi with $3.75 \%$ p-distance (Table 1).

Distribution. Russia: the Altai Republic, Southern Ural and probably the Republic of Khakassia.

Remark. The record of $C$. repentis from the Republic of Khakassia (AkULov et al. 2019) most likely belongs to $C$. procurvella.

\section{Caryocolum atrum sp. nov.}

(Figs 10-12, 19, 21)

Records. Povolný (1973, as Caryocolum pr. blandella); BIDZILYA (2002, as C. blandella, misidentification); HuEMER et al. (2017, as Monochroa sp. 1).

Type material. Holotype: (TLMF): RUSSIA: Altai Republic: Kosh-Agach district, north of the Ukok Plateau, small side valley in the catchment area of the Zhumaly River, $49^{\circ} 30^{\prime} 17.85^{\prime \prime} \mathrm{N}, 88^{\circ} 05^{\prime} 50^{\prime \prime} \mathrm{E}$, 2.400-2.500 m a.s.1., 4.-6.viii.2016 (gen. slide P. Huemer GEL 1277 ), (Barcode TLMF Lep 20454), Huemer P. \& Wiesmair B. leg. Paratypes: $7 \delta 2$ (TLMF): the same collecting data as holotype (gen. slide P. Huemer GEL 1278 \%), (Barcode TLMF Lep 20455); Kosh-Agach district, $15 \mathrm{~km} \mathrm{~N}$ of Beltir near Chagan river, $2200 \mathrm{~m}$ a.s.1., steppe, 16.viii.2000, 1 (gen. slide 180/18, Bidzilya), O. Bidzilya leg. (ZMKU). MONGOLIA: Снӧvsgöl AIмак: Alag Mort, 42 km NO von Pass Chaldzan Sogotyn davaa, am Fluss Tesijn gol [ $=42 \mathrm{~km}$ NE of Chaldzan Sogotyn davaa pass, at Tesijn gol river], 1900 m, 14.viii.1968, $1 \precsim$ (gen. slide Gz. 3967), exp. Dr. Z. Kaszab, 1968 (Nr. 1109), with additional label 'Caryocolum pr. blandella. det. Povolný' (SMNK).

Description. Adult (Figs 10-12). Wingspan 10.5-13.5 $\mathrm{mm}$. Head, thorax and tegulae blackish brown. Segment 2 of labial palpus blackish brown, upper surface mottled with cream-coloured scales; segment 3 blackish brown with a few cream-coloured scales. Antenna blackish brown, with indistinct lighter rings. Forewings narrow, unicolorous glossy blackish brown, without distinct markings, in fresh specimens black spot in fold and cell weakly developed; costal margin near base and apex darker. Hindwing greybrown, little lighter than forewings. Females smaller, otherwise as males.

Variation. None.

Male genitalia (Fig. 19). Uncus rounded; tegumen very broad; transtilla with numerous spines; valva slightly 


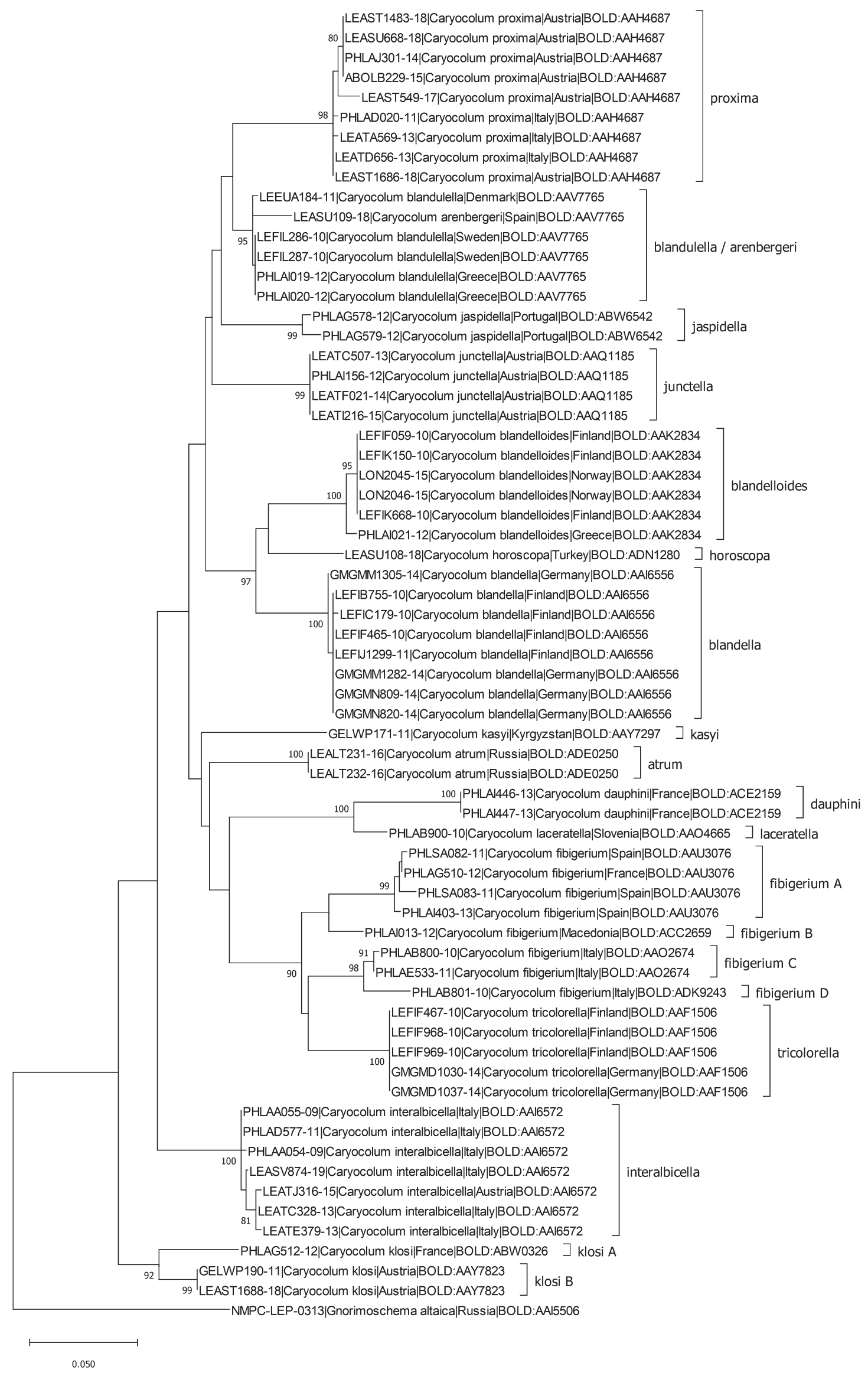

Fig. 23. Maximum likelihood tree based on DNA barcodes of the specimens from the Caryocolum interalbicella group with Gnorimoschema altaica Bidzilya, Huemer, Nupponen \& Šumpich, 2019 as an outgroup species (data from BOLD). 
Table 2. Intraspecific mean K2P (Kimura 2 Parameter) divergences, maximum pairwise distances and distance to the nearest neighbour within the C. interalbicella species-group (in \%).

\begin{tabular}{|l|c|c|l|c|}
\hline Species & Mean Intra-Sp & Max Intra-Sp & Nearest Species (NS) & Distance to NS \\
\hline Caryocolum arenbergeri & - & 0 & Caryocolum blandulella & 1.55 \\
\hline Caryocolum blandella & 0.13 & 0.36 & Caryocolum blandulella & 5.04 \\
\hline Caryocolum blandelloides & 0.24 & 0.98 & Caryocolum blandella & 5.3 \\
\hline Caryocolum blandulella & 0.21 & 0.46 & Caryocolum arenbergeri & 1.55 \\
\hline Caryocolum dauphini & 0 & 0 & Caryocolum laceratella & 5.63 \\
\hline Caryocolum fibigerium & 3.41 & 6.31 & Caryocolum tricolorella & 4.12 \\
\hline Caryocolum horoscopa & - & 0 & Caryocolum blandella & 5.08 \\
\hline Caryocolum interalbicella & 0.37 & 0.77 & Caryocolum junctella & 5.27 \\
\hline Caryocolum jaspidella & 1.08 & 1.08 & Caryocolum blandulella & 4.42 \\
\hline Caryocolum junctella & 1.12 & 2.34 & Caryocolum blandulella & 4.03 \\
\hline Caryocolum kasyi & - & 0 & Caryocolum junctella & 4.91 \\
\hline Caryocolum klosi & 2.16 & 4.28 & Caryocolum interalbicella & 5.43 \\
\hline Caryocolum laceratella & - & 0 & Caryocolum dauphini & 5.63 \\
\hline Caryocolum atrum & 0 & 0 & Caryocolum blandulella & 5.46 \\
\hline Caryocolum proxima & 0.44 & 1.08 & Caryocolum blandulella & 3.8 \\
\hline Caryocolum tricolorella & 0.14 & 0.46 & Caryocolum fibigerium & 4.12 \\
\hline
\end{tabular}

longer than sacculus, bulged distally; sacculus narrow, straight, pointed, in spike nail-shaped; posterior margin of vinculum nearly straight, slightly projected in middle and with short medial incision; saccus broad at base, gradually tapered, with narrow last third rod-like; phallus stout, straight, comparatively short, with indistinct spine in distal part.

Female genitalia (Fig. 21). Eighth segment with pair of small processes, pointing laterally. Apophysis anterior about three times length of apophysis posterior; antrum funnel-shaped, very broad posteriorly; ductus bursae slightly sclerotized near antrum; signum short slightly bent hook. Differential diagnosis. Very similar to C. unicolorellum and $C$. mongolense, from which the new species differs in the smaller size (10.5-13.5 mm compared to $15.1 \mathrm{~mm}$ in C. unicolorellum and $17-18 \mathrm{~mm}$ in C. mongolense), and in unicolorous blackish-brown and distinctly narrower wings without discal spots in forewings, with more pointed apex. Furthermore, C. mongolense has a creamish white rather than brown head. The narrow sacculus with apex pointed from both sides is the most valuable character of male genitalia for separating C. atrum sp. nov. from C. proxima (Haworth, 1828), C. blandella (Douglas, 1852), and C. blandelloides Karsholt, 1981, which have the shape of the posterior margin of the vinculum very similar to $C$. atrum sp. nov. In female genitalia the new species is most similar to $C$. blandella, but the ventromedial plate and the processes of the eight segment are indistinct. The male and female genitalia of the new species as well as DNA barcodes support its placement in the $C$. interalbicella species-group of Caryocolum (sensu Huemer 1988) (Table 2).

Etymology. The species name is the Latin adjective ater $(-a,-u m)$, referring to the black colour of the forewings.

Biology. Unknown. The majority of the type specimens were collected after a frosty night in the early morning hours at very low temperatures, at open grassy habitats partly with Betula nana as undergrowth at an altitude of
2.400-2.500 m a.s.1. (Fig. 28).

Molecular data. BIN BOLD: $\operatorname{ADE} 0250(n=2,2$ public, 2 from the Altai). The average intraspecific divergence of the barcode region is $0.0 \%$. The nearest neighbour is $C$. blandulella (Tutt, 1887) with 5.46\% p-distance (Table 2). Distribution. Russia: the Altai Republic; Mongolia.

\section{Caryocolum pullatella (Tengstrom, 1848)}

Records. HuEmER et al. (2017).

Material examined. RUSSIA: Altai RepUblic: Teletskoe lake, Artybash biol. St, 18.-22.viii.1982, $7 \delta 3$ 우, Mikkola leg. (FMNH); Kuragan valley, $15 \mathrm{~km}$ S Katanda, $1200 \mathrm{~m}$ a.s.1., taiga, 23-25.vii.1983, 1 (GU 94/481, P. Huemer), Mikkola, Hippe \& Jalava leg. (FMNH); Katun valley, $700 \mathrm{~m}$ a.s.1., near Ust-Sema village, $51^{\circ} 40^{\prime} \mathrm{N} 85^{\circ} 45^{\prime} \mathrm{E}, 23 . v i .2000,3$ of 1 우 (gen. slide 249/19 , O. Bidzilya), T. \& K. Nupponen leg. (NUPP); Ulagan district, $11 \mathrm{~km} \mathrm{NNW}$ of Aktash, $1.900 \mathrm{~m}$ a.s.1., $50^{\circ} 24^{\prime} 49.22^{\prime \prime} \mathrm{N}$,

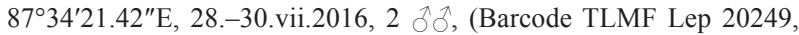
TLMF Lep 20250), P. Huemer \& B. Wiesmair leg. (TLMF); Belyashi (Dzhazator) env. (25 km NW), confluence of Argut and Karagem rivers, $49^{\circ} 51^{\prime} 56^{\prime \prime} \mathrm{N}, 87^{\circ} 10^{\prime} 22^{\prime \prime} \mathrm{E}$, rocky steppe, $1400 \mathrm{~m}, 27 .-28 . v i i .2017,1$ (Barcode NMPC-LEP-0374), J. Šumpich leg. (NMPC); Ust-Kan env. (6 km E), 5056'05"N, 8451'17", grassy steppe, meadow, $1100 \mathrm{~m}$ a.s.1., 12.vii.2014, $3 \hat{\jmath}$ (gen. slide 195/18, O. Bidzilya), J. Šumpich leg. (NMPC).

Molecular data. BIN BOLD: AAC1599 $(n=37,33$ public, 3 from the Altai). The average intraspecific divergence of the barcode region is $0.25 \%$ (maximum $0.72 \%$ ). However, several other BINs were assigned to the species C. pullatella: AAC1598 (southern and central Europe), AAC1597 (Canada), AAH6281 (Canada), AAH4284 (Canada, USA), ACI5465 (USA), which can indicate cryptic diversity there. The Altai specimens are clustered together with North-European records (Norway, Finland).

Distribution. Holarctic according to the current concept. In Russia it was recorded from the European part to Zabaikalskiy krai in the east (PonOMARENKo 2008).

Remark. Caryocolum pullatella was described from Finland (cf. Huemer 1988). Based on the barcode data, the Altai specimens belong to true $C$. pullatella, with a distribution possibly restricted from northern Europe to 

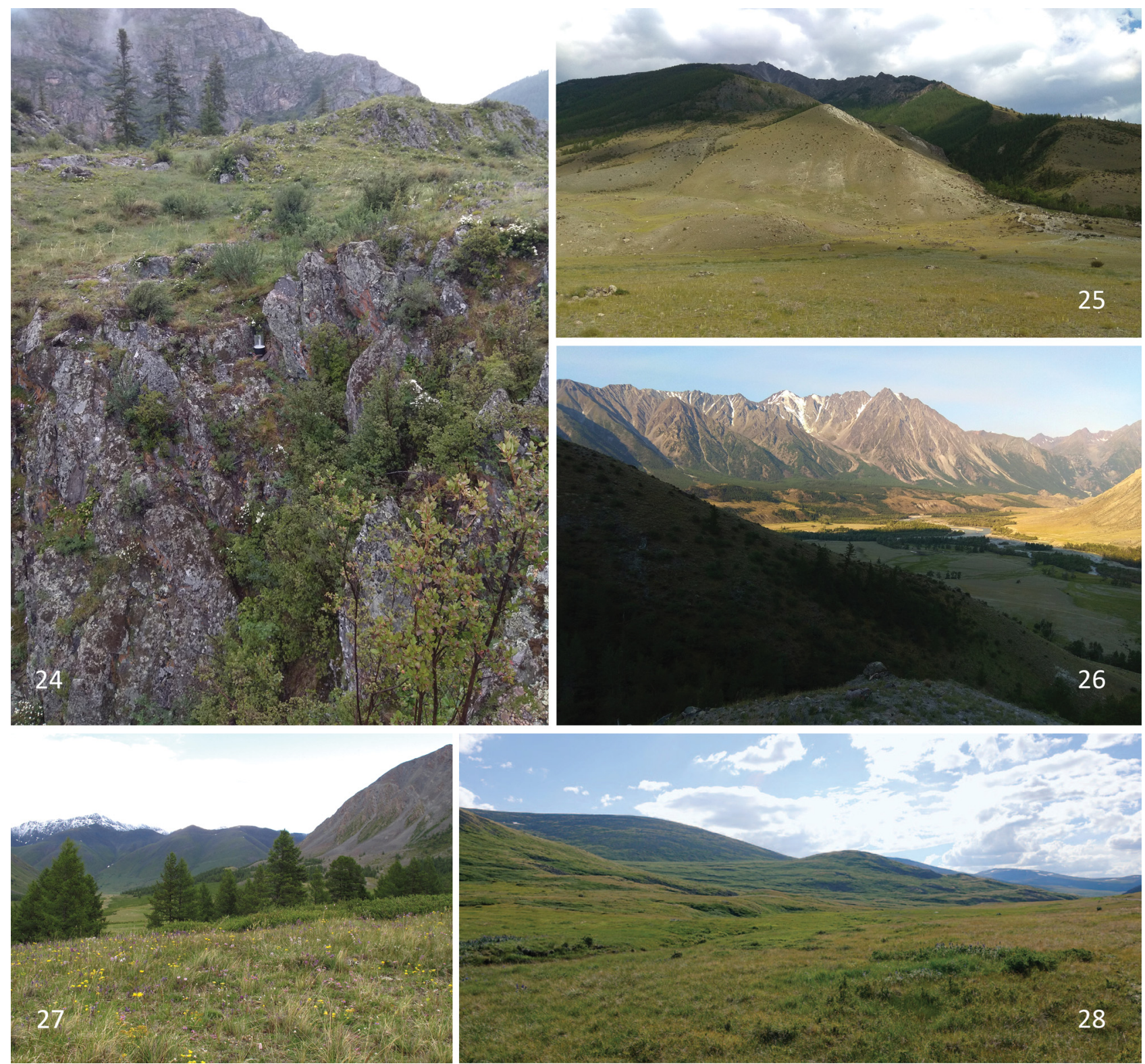

Figs 24-28. Habitats of Caryocolum species in Altai Mts. 24 - Aktash, habitat of C. oculatella (Thomann, 1930) and C. tetrameris (Meyrick, 1926), the portable light trap in the middle of the photo; 25-26 - confluence of Argut and Karagem rivers, $25 \mathrm{~km}$ NW Dzhazator, habitat of $C$. arenariella (Benander, 1937), C. petryi (Hofmann, 1899), C. petrophilum (Preissecker, 1914), C. procurvella sp. nov., and C. tetrameris (Meyrick, 1926); 25 - view of the hill where Caryocolum species were collected; 26 - view of the landscape from the collecting site, in the background peaks of South Chuy ridge; 27 - Tara valley, $56 \mathrm{~km} \mathrm{SE}$ of Dzhazator, habitat of C. arenariella (Benander, 1937), C. cassella (Walker, 1864), C. leucomelanella (Zeller, 1839), and C. tetrameris (Meyrick, 1926); 28 - Ukok plateau, habitat of C. atrum sp. nov. Photo J. Sumpich (24-27) and B. Wiesmair (28).

southern Siberia, whereas other populations probably represent cryptic species which should be revised (see also NAZARI \& LANDRY 2012).

\section{Caryocolum tetrameris (Meyrick, 1926)}

(Figs 13-15, 20, 22)

Records. Huemer et al. (2017, as Caryocolum sp.).

Material examined. RUSSIA: Altai Republic: Dzhazator valley, near Tara river, $56 \mathrm{~km}$ SE of Belyashi, 49 $39^{\prime} 45^{\prime \prime} \mathrm{N}, 88^{\circ} 14^{\prime} 28^{\prime \prime} \mathrm{E}, 2300 \mathrm{~m}$ a.s.1., 25.-26.vii.2017, 69 7 오 (gen. prep. 19983, 19984, 19985, J. Šumpich) (Barcode NMPC-LEP-0367), J. Šumpich leg. (NMPC, ZMKU, ZMUC); Kosh-Agach district, 17 km NNE of Kokorya, Chikhacheva Mountains Range, Talduair Mountains, Sajlyugem valley, 2.200 m a.s.1., $50^{\circ} 01^{\prime} 15.37^{\prime \prime} \mathrm{N}, 89^{\circ} 13^{\prime} 43.65^{\prime \prime} \mathrm{E}, 30$.vii.-2.viii.2016, $2 \precsim$ (gen. slide GEL 1263 A. P. Huemer) (Barcode TLMF Lep 20363, TLMF Lep 20364), P. Huemer \& B. Wiesmair leg. (TLMF); Kosh-Agach district, 10 km NE of Kosh-Agach, Kurai Mountains Range, Tabozhok valley, $2.100 \mathrm{~m}$ a.s.1., $50^{\circ} 04^{\prime} 32.36^{\prime \prime} \mathrm{N}, 88^{\circ} 43^{\prime} 41.83^{\prime \prime} \mathrm{E}, 2 .-4 . v i i i .2016,3 \hat{\jmath}{ }^{\prime}$ (gen. slide GEL $1264 \hat{\lambda}$, P. Huemer) (Barcode TLMF Lep 20380), P. Huemer \& B. Wiesmair leg. (TLMF); Ulagan district, $10 \mathrm{~km}$ NE Aktash village, Kurai Mts range, between Korumdyajry and Yarlyamry rivers, 2150 m a.s.1., $50^{\circ} 19^{\prime} \mathrm{N}, 87^{\circ} 43^{\prime} \mathrm{E}, 6 .-8 . v i i i .2016,9 \partial^{\circ} 1$ o , P. Huemer \& B. Wiesmair leg. (TLMF); Aktash vill., 50 $10^{\prime} 12^{\prime \prime} \mathrm{N} ; 87^{\circ} 36^{\prime} 00^{\prime \prime} \mathrm{E}$, grassy steppe, rocks, 1400 m, 11.vii.2014, $1 \precsim$ (Barcode NMPC-LEP-0361), J. Šumpich leg. (NMPC); the same data but 21.vi.2015, $2 \lesssim 2$ 우 (gen. slide 280/17; 286/17 9 ; 171/18, O. Bidzilya) (NMPC); Belyashi (Dzhazator) env. (25 km NW), confluence of Argut and Karagem rivers, $49^{\circ} 51^{\prime} 56^{\prime \prime} \mathrm{N}$, $87^{\circ} 10^{\prime} 22^{\prime \prime} \mathrm{E}$, rocky steppe, $1400 \mathrm{~m}, 1 \delta 8$ ${ }_{+}$, J. Šumpich leg. (NMPC); Kosh-Agach Distr., Kurai env. (6.5 km SW), 50¹0'35"N; 8753'55"E, grassy steppe, 1550 m, 30.vii.2017, 2 ค, J. Šumpich leg. (NMPC).

Molecular data. Genetically variable species, clustering into two BINS: BIN BOLD: ADE0005 $(n=4,4$ public, 
4 from the Altai); BOLD: ADE0329 ( $\mathrm{n}=1$, from the Altai). The average intraspecific divergence of the barcode region in BIN BOLD: ADE0005 is $0.24 \%$ (maximum $0.32 \%$ ) whereas the p-distance to the second cluster is $3.56 \%$. C. sciurella (Walsingham, [1908]) occurring on the Canary Islands and Madeira, is the nearest neighbour with $6.8 \%$ p-distance.

Distribution. Turkey, Iran and central Asia (HUEMER 1988), Russia: the Altai Republic. New species for Russia.

Remark. Specimens of both genetic clusters occur sympatrically and fully agree in external and genitalia morphology, thus clearly indicating conspecificity.

Material from the Altai Mts. is tentatively identified as C. tetrameris, a species described from Turkey which may include cryptic diversity. However, lack of material and absence of comparative genetic data do not allow a final taxonomic assessment for the time being.

\section{Discussion}

The lepidopteran fauna of the Russian Altai Mts. is rather poorly known, and only some groups, e.g. Hesperioidea, Papilionoidea, Noctuidae and a few others, were studied in detail (e.g. TshiKOLOVETs et al. 2009, VOLYNKIN 2012). In comparison, small moths (Microlepidoptera) were studied only patchily, with exceptional revisionary works on Pterophoridae (UstJuzhanin \& Kovtunovich 2007, 2008, 2017). So far, only a few publications have been devoted to the family Gelechiidae and their results have been summarized in the checklist of Russian Lepidoptera (PonOMARENKo 2008); however, without faunistic data. Therefore this is the first complex faunistic study of this group taking into account all available information. One of the most important papers dealing with lepidopteran fauna of the Ukok plateau in the south-eastern part of the Altai Mts. covers 17 species of Gelechiidae but no species of the genus Caryocolum (BIDZILYA et al. 2002). On the other hand, several species of the latter genus were published from the Altai by BiDziLYA (2002) and later by Huemer et al. (2017). According to these studies, the genus Caryocolum seems to be well explored in the Russian Altai, although discovery of additional new species cannot be excluded. In comparison, other gelechiid genera in the Altai Mts. and in the adjacent regions appear to be much less investigated, and very likely many new species will be discovered in the future.

\section{Acknowledgements}

We are grateful to Paul D. N. Hebert and the entire team at the Canadian Centre for DNA Barcoding (CCDB, Guelph, Canada) for carrying out the sequence analyses. We are furthermore indebted to Jari Junnilainen for providing the photos of Caryocolum procurvella collected in southern Ural, and to Benjamin Wiesmair for providing Figures 23 and 28. Benjamin Wiesmair, Christian Wieser and Marek Dvořák are thanked for support during fieldwork and for supplying us with important data. Jitka Ansari (London, United Kingdom) helped us a lot with improvements and corrections of English. We also thank both reviewers, Ole
Karsholt and Sergey Sinev, for their valuable comments. Jan Šumpich is very grateful to Petr Kment for significant support in context of DNA barcoding of moths. The work was supported by the Ministry of Culture of the Czech Republic (DKRVO 2019-2023/5.I.b, National Museum, 00023272) (J. Šmpich), by the Promotion of Educational Policies, University and Research Department of the Autonomous Province of Bolzano - South Tyrol (project "Genetische Artabgrenzung ausgewählter arktoalpiner und boreomontaner Tiere Südtirols) (P. Huemer), and by the State Budget Program "Support for the Development of Priority Areas of Scientific Research" (Code: 6541230) (O. Bidzilya).

\section{References}

AARVIK L., BENGTSSON B. Å., ELVEN H., IVINSKIS P., JÜRIVETE U., KARSHOLT O., MUTANEN M. \& SAVENKOV N. 2017: Nordic-Baltic Checklist of Lepidoptera. Norwegian Journal of Entomology, Supplement 3: 1-236.

AKULOV E. N., KIRICHENKO N. I. \& PONOMARENKO M. G. 2018: Contribution to Microlepidoptera Fauna of the South of Krasnoyarsk Territory and the Republic of Khakassia. Entomological Review 98(1): 49-75. https://doi.org/10.1134/S0013873818010074

AKULOV E. N., PONOMARENKO M. G. \& KIRICHENKO N. I. 2019: Exploring fauna of Microlepidoptera in South Siberia: novel regional records and interception of quarantine species. Journal of Asia-Pacific Biodiversity 12: 597-612.

BIDZILYA O. V. 2002: On the distribution of Gelechiid Moths (Lepidoptera, Gelechiidae) in the Southern Siberia. Contribution 1. The Kharkov Entomological Society Gazette 9(1-2) [2001]: 64-72 (in Russian, English summary).

BIDZILYA O. V. 2005: On the distribution of Gelechiid Moths (Lepidoptera, Gelechiidae) in Siberia. Contribution 2. Proceeding of the Zoological Museum of Kiev Taras Shevchenko National University 3: 7-19 (in Russian, English summary).

BIDZILYA O. V. 2009: On the distribution of gelechiid moths (Lepidoptera, Gelechiidae) in Siberia. Contribution 3. Proceedings of the Zoological Museum of Kiev National Taras Shevchenko University 5: 3-13.

BIDZILYA O. V., BUDASHKIN Y. I. \& KOSTJUK I. Y. 1998: Additions to the fauna of Microlepidoptera of Transbaikalia. Journal of Ukrainian Entomological Society 4: 33-63 (in Russian, English abstract).

BIDZILYA O. V., BUDASHKIN Y. I. \& NOREIKA R. 2006: Description of Parornix altaica sp. n. with new distributional data on Parornix mixta (Triberti), P. tenella (Rebel) and P. kugitangi Noreika (Lepidoptera, Gracillariidae). Acta Zoologica Lituanica 6: 210-214.

BIDZILYA O., HUEMER P., NUPPONEN K. \& ŠUMPICH J. 2019: A review of some new or little-known species of the genus Gnorimoschema (Lepidoptera, Gelechiidae) from the Palaearctic region. ZooKeys 857: 105-138.

BIDZILYA O. \& NUPPONEN K. 2018: New species and new records of gelechiid moths (Lepidoptera, Gelechiidae) from southern Siberia. Zootaxa 4444(4): 381-408.

BUCHNER P., JUNNILAINEN J. \& NUPPONEN K. 2019: Agonopterix sideensis from Turkey and Exaeretia lvovskyi from Russia, two new species of Depressariidae (Lepidoptera) from the Palaearctic region, and the transfer of Exaeretia montuosella (Hannemann, 1976) into the genus Agonopterix Hübner, [1825]. Miscellaneous Papers (Ankara) 178: 1-26.

EDGAR R. C. 2004: MUSCLE: multiple sequence alignment with high accuracy and high throughput. Nucleic Acids Research 32(5): 1792-1797.

FALKOVITSH M. \& BIDZILYA O. 2006: The Turanian gelechiid moths of the tribe Gnorimoschemini (Lepidoptera, Gelechiidae) living on plants of the family Chenopodiaceae, with descriptions of new species. Proceedings of the Zoological Museum of Kiev National Taras Shevchenko University 4: 62-104 (in Russian, English summary). 
GAEDIKE R. \& ŠUMPICH J. 2017: Tinea altaica sp. nov. and new records from Altai Republic (Lepidoptera: Meessiidae, Tineidae, Douglasiidae, Epermeniidae, Glyphipterigidae: Acrolepiinae). Acta Entomologica Musei Nationalis Pragae 57: 259-273.

GRANGE J.-C. \& NEL J. 2012: Caryocolum dauphini n. sp., un endémique du Sud-Ouest alpin découvert dans le Parc national du Mercantour (Lep. Gelechiidae, Gnorimoschemini). Oreina 17: 24-25.

HUEMER P. 1988: A taxonomic revision of Caryocolum (Lepidoptera, Gelechiidae). Bulletin of the British Museum (Natural History), Entomology 57(3): 439-571.

HUEMER P. 1989: Neue und wenig bekannte Arten der Gattung Caryocolum Gregor \& Povolny, 1954, aus Südwestasien (Lepidoptera, Gelechiidae). Mitteilungen der Münchner Entomologischen Gesellschaft 79: 127-142.

HUEMER P. 1992: Caryocolum transiens spec. nov. aus Nepal. Spixiana 15: 89-91.

HUEMER P. \& KARSHOLT O. 2010: Gelechiidae II (Gelechiinae: Gnorimoschemini). In: HUEMER P., KARSHOLT, O. \& NUSS, M. (eds): Microlepidopera of Europe 6. Apollo Books, Stenstrup, 586 pp.

HUEMER P. \& KARSHOLT O. 2011: A new species of Caryocolum from Montenegro (Lepidoptera: Gelechiidae). Zeitschrift der Arbeitsgemeinschaft Österreichischer Entomologen 63: 37-42.

HUEMER P., KARSHOLT O., AARVIK L., BERGGREN K., BIDZILYA O., JUNNILAINEN J., LANDRY J.-F., MUTANEN M., NUPPONEN K., SEGERER A., ŠUMPICH J., WIESER C., WIESMAIR B. \& HEBERT P. D. N. 2020: DNA barcode library for European Gelechiidae (Lepidoptera) suggests greatly underestimated species diversity. ZooKeys (submitted).

HUEMER P., KARSHOLT O. \& MUTANEN M. 2014: DNA barcoding as a screening tool for cryptic diversity: an example from Caryocolum, with description of a new species (Lepidoptera, Gelechiidae). ZooKeys 404: 91-111.

HUEMER P., WIESER C., WIESMAIR B., SINEV S. YU., WIESER C. \& YAKOVLEV R. V. 2017: Schmetterlinge (Lepidoptera) des Altai-Gebirges (Südsibirien, Russland) - Eindrücke einer internationalen Expedition im Spätsommer 2016. Carinthia II 207/127: 537-564.

JUNNILAINEN J., KARSHOLT O., NUPPONEN K., KAITILA J.-P., NUPPONEN T. \& OLSCHWANG V. 2010: The gelechiid fauna of the southern Ural Mountains, part II: list of recorded species with taxonomic notes (Lepidoptera: Gelechiidae). Zootaxa 2367: 1-68.

KLIMESCH J. 1953-1954: Die an Caryophyllaceen lebenden europaeischen Gnorimoschema Busck (Phthorimaea Meyr.)-Arten. Zeitschrift der Wiener Entomologischen Gesellschaft 38 [1953]: 225-239, 275-282, 311-319, 39 [1954]: 273-288, 335-341, 357-362.

KUMAR S., STECHER G., LI M., KNYAZ C. \& TAMURA K. 2018 : MEGA X: Molecular Evolutionary Genetics Analysis across computing platforms. Molecular Biology and Evolution 35: 1547-1549. https: //doi.org/10.1093/molbev/msy096

LEPIFORUM 2019: Lepiforums-Europaliste der Schmetterlinge. Website http://www.lepiforum.de/lepiwiki.pl?Caryocolum_Oculatella. (Accessed: 9 October.2019).

LI H.-H. 2002: The Gelechiidae of China (I), (Lepidoptera, Gelechiidae). Nankai University Press, Tianjin, 538 pp.

LI H. \& ZHENG Z. 1995: A new species of the genus Caryocolum (Lepidoptera: Gelechiidae) from China. Entomotaxonomia 17(4): 293-295.

NAZARI V. \& LANDRY J.-F. 2012: Gnorimoschemini fauna of Alberta (Lepidoptera: Gelechiidae). Report prepared for the Alberta Lepi- dopterists' Guild. AB, Edmonton, 129 pp. Available from: http:// www.albertalepguild.ca/projects/faunalinventories/ (accessed 10 October 2019).

NEL J. \& REQUENA E. 2017: Description d'une nouvelle espèce du groupe de Caryocolum amaurella (Hering, 1924), découverte dans les Pyrenénées: C. tredosella sp. n. (Lepidoptera, Gelechiidae). Revue de l'Association Roussillonnaise d'Entomologie 26(4): 177-179.

PONOMARENKO M. G. 2008: Gelechiidae. Pp. 87-106+327-329. In: SINEV S. Yu. (ed.): Katalog Cheshuekrylykh (Lepidoptera) Rossii. (Catalogue of the Lepidoptera of Russia). KMK Scientific Press, St. Petersburg-Moscow, 424 pp (in Russian, English abstract).

PONOMARENKO M. G. 2016: Gelechiidae. Pp. 115-140. In: LELEJ A. S. (ed.): Annotated catalogue of the insects of Russian Far East. Vol. II. Lepidoptera. Dalnauka, Vladivostok, 812 pp (in Russian).

POVOLNÝ D. 1973: Ergebnisse der zoologischen Forschungen von Dr. Z. Kaszab in der Mongolei (nr. 267) (Tribus Gnorimoschemini, Lep., Gelechiidae). Přirodovědné Práce Ústavu Československé Akademie Vĕd v Brně 3(12): 1-42.

RATNASINGHAM S. \& HEBERT P. D. N. 2007: BOLD: The Barcode of Life Data System (http: //www.barcodinglife.org). Molecular Ecology Notes 7: 355-364.

RATNASINGHAM S. \& HEBERT P. D. N. 2013: A DNA-based registry for all animal species: the Barcode Index Number (BIN) system. PLoS ONE 8(8) (e66213): 1-16.

SINEV S. YU., BARYSHNIKOVA S. V., LVOVSKY A. L., ANIKIN V. V., ZOLOTUHIN V. V. 2017: Volgo-Ural Microlepidoptera described by E. Eversmann. Pp. 374-379, pl. 1, 2. In: ANIKIN V. V., SACHKOV S. A. \& ZOLOTUHIN V. V. (eds.): "Fauna Lepidopterologica Volgo-Uralensis": from P. Pallas to present days. Proceedings of the Museum Witt Munich, Vol. 7. Museum Witt Munich \& Nature Research Center Vilnius, Munich-Vilnius, 683 pp.

ŠUMPICH J., BIDZILYA O. \& PONOMARENKO M. 2019: Sophronia salaganella sp. n. from the Russian Altai and new data on Palaearctic Sophronia Hübner, [1825] species (Lepidoptera, Gelechiidae). Zootaxa 4577(2): 348-360.

TAMURA K. 1992: Estimation of the number of nucleotide substitutions when there are strong transition-transversion and $\mathrm{G}+\mathrm{C}$-content biases. Molecular Biology and Evolution 9: 678-687.

TSHIKOLOVETS V. V., YAKOVLEV V. R. \& KOSTERIN E. O. 2009: Butterflies of Altai, Sayans and Tuva (South Siberia). Tshikolovets Publications (Kyiv-Pardubice), 374 pp., 48 colour plates.

USTJUZHANIN P. Ya. \& KOVTUNOVICH V. N. 2007: Fauna of Plume Moths (Lepidoptera, Pterophoridae) of the Altai Mts. within the limits of Russia and Kazakhastan. Altai Zoological Journal 1: 43-51.

USTJUZHANIN P. YA. \& KOVTUNOVICH V. N. 2008: Additions and corrections to the paper "Fauna of Plume Moths (Lepidoptera, Pterophoridae) of the Altai Mts., within the limits of Russia and Kazakhstan" by P. Ya. Ustjuzhanin and V. N. Kovtunovich. Altai zoological journal 2: 87-95.

USTJUZHANIN P. YA. \& KOVTUNOVICH V. N. 2017: New species of plume moths (Lepidoptera: Pterophoridae) from highlands of the Altai-Sayan mountainous country. Russian Entomological Journal 26(3): 267-268.

VOLYNKIN A.V. 2012. Noctuidae of the Russian Altai (Lepidoptera). Proceedings of the Tigirek State Natural Reserve 5, Barnaul, Artika, 339 pp. 